\title{
Effect of aqueous extract of Rosemary officinalis on cytotoxicity of CCL4 induced albino male mice

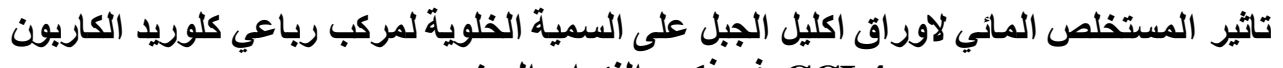 CCL4
}

Ruqaya Mohammed Ibrahim

College of Biotechnology/ Al- Nahrain University

$$
\text { كلية التقنيات الاحيائية ابراهيم جائمه النهرين }
$$

E- mail: ruqaia.alezzy83@yahoo.com

\begin{abstract}
This study focused the line on the effect of aqueous extract of Rosemary officinalis, as well as, effect of toxic compound $\mathrm{CCL} 4$, on micronucleus formation and mitotic index assay in albino male mice. This work started at September 2017 at Biotechnology Research center \Al-Nahrain University, by using 20 albino male mice. The result indicated that aqueous extract of rosemary caused significant increased in mitotic index and decrease micronucleus formation for two doses tested 50,100 $\mathrm{mg} / \mathrm{kg}$ in comparison with negative and positive controls, also the results revealed that CCL4 showed significant mutagenic action on biological system of treated mice by increased frequency of micronucleus formation and decreased the percentage of mitotic index in bone marrow cells. Pre-and post -treatment between aqueous extract and CCLA were also made. The results of pre and post treatment with rosemary extract were also caused a significant decreased in micronucleus formation and increase the percentage of mitotic index for two doses 50,100 $\mathrm{mg} / \mathrm{kg}$ in comparis on with its corresponding controls which caused increased in the frequencies of micronucleus formation and decrease the percentage of mitotic index in bone marrow cells. Conclusions: Rosemary officinalis enhanced immunity, reduced mutagenic effects against cytotoxicity of CCLA.
\end{abstract}

Key words: rosemary officinalis, CCL4, Mitotic Index, Micronucleus percentage

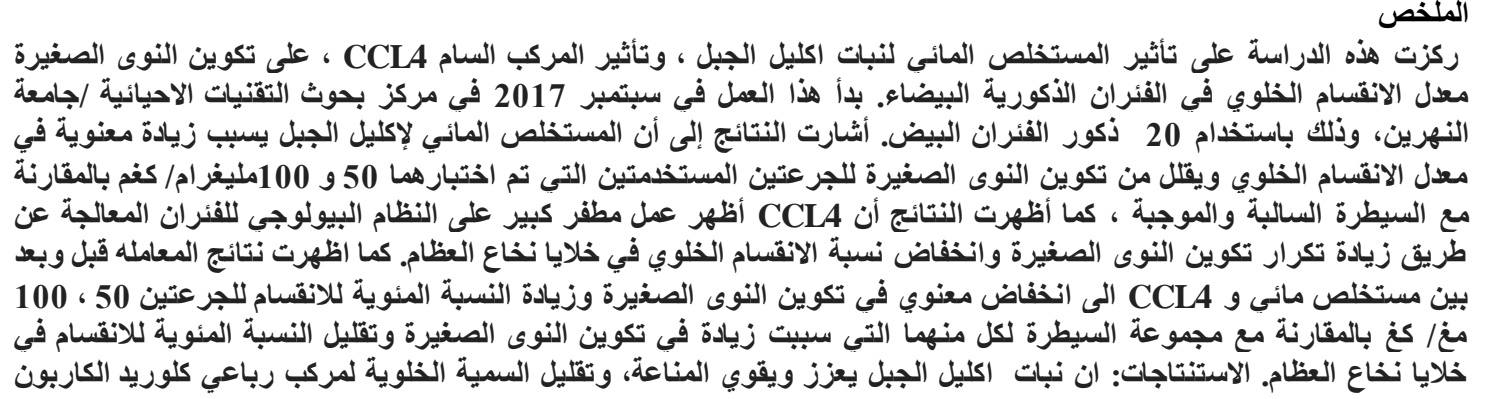

الكلمات الدالة: إكليل الجبل، CCL4 رباعي كلوريد الكاربون، الانقسام الخلوي، النوى الصغيرة

\section{Introduction}

The relationship of humans and animals with plants obviously originated with the beginning of life on earth [1] when these plants abounding much of the shelter, oxygen, food and medicine needed by higher life forms [2]. Remedial plants have long played essential roles in the treatment of diseases all over the world [3]. Some of these properties are antimicrobial, anti-cancer, anti-diabetic [4], anti-atherosclerosis [5], immunomodulatory [6], in addition to use as source for a extensive variety of natural antioxidants [7]. Rosemary (Rosmarinus officinalis L.), which belongs to the family Lamiaceae, is an aromatic, evergreen, high shrub with upright stems, whitish-blue flowers and dark green leaves [8].The therapeutic nature of rosemary extract is related to its content of important active constituents mainly diterpenes (e.g. carnosic acid); phenolic acids (e.g. rosmarinic acid) and flavonoids that derived from two frequent flavones: apigenin and luteolin [9]. Rosemary extracts, chiefly derived from the leaves, are common herbal products used as flavoring and antioxidant agents in food processing and cosmetics [10]. As naturally stirring antioxidants, they are ideal to synthetic antioxidants [11]. Moreover, the biological properties of rosemary have been credited to its phytochemical composition rich in (poly) phenolic compounds, mainly diterpenoids such as carnosic acid and carnosol [12].Rosemary extracts and its dried leaf contains an essential oil (0.6-2\%) of varying composition [13].Rosemary essential oil extract is also used as an antibacterial, antifungal [14] and anticancer agent [15]. 
Carbon tetrachloride (CCl4) is a manufactures chemical used for many domestic purposes. The toxicity of CCl4 was studied by several investigators [16]. CCl4 Carbon tetrachloride toxicity has resulted in many cases of poisoning by inhalation, ingestion or absorption [17]. Prolonged exposure to carbon tetrachloride induced histopathological features such as inflammatory leucocytes' infiltration, necrosis , fibrosis, cirrhosis and sometimes may lead to tumors [18]. It induced liver fibrosis, enhanced lipid peroxidation, increases alanine aminotransferase (ALT) and causes collagen deposition in liver tissue [19]. Poisoning by CCl4 induced toxic injury to both liver and kidney [20].

\section{Materials and Methods \\ Plant collection and identification}

The leaves of plant were collected from the confined markets during September (2016), which had been identified previously by National Herbarium of Iraq. The leaves were left at room temperature to dry, and after dryness, they were powdered with a coffee grinder.

Preparation of plant extract

The plant leaves was extracted with distilled water. The air dried leaves powdered using coffee grinder [21]. Fifty grams of the leaves powder were extracted for three hours in $250 \mathrm{ml}$ of the solvent (distilled water) using the soxhlet device and the source of heating was a boiling water bath $100^{\circ} \mathrm{C}$. The leaf extract solution was then evaporated at $45^{\circ} \mathrm{C}$ using a rotary evaporator and the resultant crude extract was frozen at -20C until use to prepare the required doses [22].

Preparation of carbon tetrachloride (CCL4): carbon tetrachloride solution was used at concentration of $0.2 \% \mathrm{CCl}_{4}$ in olive oil [21].

Laboratory animals

Albino Swiss male mice (Mus musculs) were supplied by the Biotechnology Research Centre (AlNahrain University). Their age was 8-10weeks, and their weight was 23-27 grams. They were divided into groups, and each group was kept in separate plastic cage (details of the groups are given in the section of experimental design). The animals were maintained at a temperature of 23-25C, and they had free access to food (standard pellet) and water.

\section{Experimental design}

The experiments were planned to estimate the effect of rosemary officinalis aqueous extract on albino male mice, as well as, their role in modulating the effect of toxic compound CCL4. Therefore, such as evolution were carried out through two stages:

\section{First stages}

In this stage, the effect of two selected doses (50 and $100 \mathrm{mg} \backslash \mathrm{kg}$ ) of rosemary aqueous extracted and CCL4 were investigated. The selection of these doses based on previous investigation by [23] who found that rosemary aqueous had no toxicity between 50 and $500 \mathrm{mg} / \mathrm{kg}$ of body weight. Therefore, the animals were divided in to four groups, each groups contained (4) animals:

1. Group I: the animals were treated with distilled water (Negative controls).

2. Group II: the animals were treated with first dose of rosemary extract $(50 \mathrm{mg} / \mathrm{kg})$.

3. Group III: the animals were treated with second dose of rosemary extract $(100 \mathrm{mg} / \mathrm{kg})$.

4. Group IV: the animals were treated with CCL4 $(0.2 \% \mathrm{mg} / \mathrm{kg})$ (positive controls).

The tested materials were injected intraperitoneally as a single dose $(0.1 \mathrm{ml})$ per a day and for 7 days. The mice were sacrificed in day 8 .

\section{Second stages}

In this stage, an interaction (pre- and post-treatment) between the two doses of rosemary aqueous extract and CCL4were carried out.

In pre-treatment interaction, the plant extract was given for 6 days (single dose $0.1 \mathrm{ml} /$ days), while CCL4 was given in day 7, and then animals were sacrificed in day8. The tested materials were administrated intraperitoneally $(0.1 \mathrm{ml})$.

In post treatment interaction, the animals was given CCL4 on day one, while the plant extract was given in day 2 till day 7 (single dose $0.1 \mathrm{ml} /$ day), and then animals were sacrificed in day 8 . The materials were administrated intraperitoneally $(0.1 \mathrm{ml})$.

For both treatments, controls groups were paralleled with the two types of interactions.

\section{Investigation Parameters}

Metaphase index assay

Metaphase index was determined for cells obtained from bone marrow, following the procedure of [24]. After mice injected intraperitoneally with $0.25 \mathrm{ml}$ of colchicines for 2 hours, the animals was sacrificed to obtain femur bone. After that, its cellular contents were collected by using normal physiological saline $5 \mathrm{ml}$. The cells were suspended in a test tube and centrifuged $2000 \mathrm{rpm} / \mathrm{min}$ for 10 minutes. The cell deposit was suspended in $5 \mathrm{ml}$ of a warm 37C hypotonic solution (KCL; $0.075 \mathrm{M}$ ). Then the tubes were incubated in water path $37 \mathrm{C}$ for 30 minutes, and then the tubes were centrifuged at 
$2000 \mathrm{rpm}$ for $10 \mathrm{~min}$. Finally, five $\mathrm{ml}$ of the fixative solution was added a drop wise to the cell deposit, the tubes were incubated in the refrigerator $4 \mathrm{C}$ for 30 minutes and successive centrifuged steps were made $2000 \mathrm{rpmlmin}$. The cell suspension was dropped on clean slides at $20 \mathrm{~cm}$ height then it was stained with Giemsa stain for 15 minutes and rinsed with distilled water and at least 1000 cells were examined under oil emersion lens. The percentage of metaphase cells (metaphase index) was recorded using the following equation:

\section{Metaphase index $(\%)=$ \\ Total count}

\section{Micronucleus formation assay}

To carry out the assessment of micronucleus formation, the procedure of [25] was followed with some modifications, which is outlined in the following steps :

The mouse was sacrificed by cervical dislocation, and then dissected to obtain the femur. After cutting both ends of the bone, it was wrapped up from the middle with a forceps in a vertical position over the edge of a test tube, and then the cellular content was collected with a heat inactivated human AB plasma $2 \mathrm{ml}$. After that, the test tube was centrifuged $1000 \mathrm{rpm}$ for 10 minutes. The cellular deposit was gently mixed, and a thin smear was made on a clean slide, and air-dried at room temperature .The smear was fixed with absolute methanol for 5 minutes, and then air-dried at room temperature, followed by staining with Giemsa stain for 15 minutes, and rinsed with distilled water. The slides were examined under oil immersion lens $100 \mathrm{X}$, and at least 1000 polychromatic erythrocytes (PCE) were examined for the presence of micronucleus formation. The micronucleus index was obtained using the following equation:

$$
\text { Micronucleus Index (micronucleus/cell)=( } \left.\frac{\text { Number of Micronuclei }}{\text { Total Count of PCE }}\right) \times 100
$$

Statical analysis

The values of the investigated parameters were given in terms of mean \pm standard errors (SE), and differences between means were assessed by analysis of variance (ANOVA) followed by least significant difference (LSD) or Duncan test, using the computer programme SPSS version 13.0. The difference was considered significant when the probability value was equal or less than 0.05.All as sessments were based on four observations (four mice) [26].

Results

Mitotic index of bone marrow cells:

The results indicated that the mitotic index of bone marrow cells in mice treated with distilled water (negative control) was $(3.00 \pm 0.14 \%)$ and such index was decreased to $(1.70 \pm 0.06 \%)$ when mice was treated with CCL4 (positive control).Treatment of animals with the two doses of rosemary aqueous extract, revealed that the percentage increased to $(7.34 \pm 0.75$ and $5.35 \pm 0.32 \%)$ for (50 and $100 \mathrm{mg} \backslash \mathrm{kg})$ respectivelyTable (1).

Table (1): Mitotic index of bone marrow cells (mean \pm stranded error) in albino male mice treated with aqueous extract of rosemary leaves, distilled water (negative control) and CCLA (positive control).

\begin{tabular}{|c|c|c|}
\hline Groups & $\begin{array}{c}\text { Dose } \\
(\mathbf{m g l k g})\end{array}$ & $\begin{array}{c}\text { mean } \pm \text { standard error (S.E) } \% \\
\text { of mitotic index }\end{array}$ \\
\hline$\overline{\text { Positive controls(CCL4) }}$ & $\overline{0.2}$ & $1.70 \pm 0.06^{D}$ \\
\hline $\begin{array}{l}\text { Negative control (distilled } \\
\text { water) }\end{array}$ & 0.00 & $3.00 \pm 0.14^{C}$ \\
\hline Rosemary aqueous extract & 50 & $7.34 \pm 0.75^{A}$ \\
\hline Rosemary aqueous extract & 100 & $5.35 \pm 0.32^{\text {B }}$ \\
\hline
\end{tabular}

Different letters in same column: significant difference $(\mathrm{P} \leq \mathbf{0 . 0 0 5})$ between means .

\section{Micronucleus formation in bone marrow}

The micronucleus formation observed with incidence of $(0.007 \pm 0.008$ micronucleus Icell) in animals treated with distilled water (negative control), but when mice treated with CCL4 appreciably frequency increased (2.280 \pm 0.012 micronucleus lcell) Figure (1). Treating the animals with two doses 50 and $100 \mathrm{mg} / \mathrm{kg}$ of aqueous extract associated with significant reduction of micronucleus 
formation as compared to the spontaneous formation negative control $(0.010 \pm 0.011$ and $0.020 \pm 0.012$ micronucleus \cell respectively as shown in Table (2).

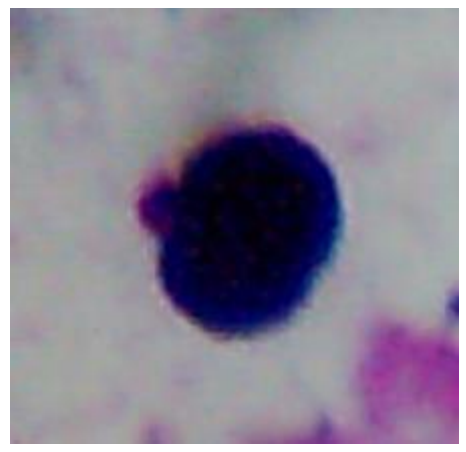

Fig (1): Micronucleous formation in bone marrow cells in mice treated with CCLA (100X; Giemsa stain)

Table (2): Micronucleus formation in bone marrow cells(mean \pm standard error) in albino male mice treated with aqueous extract of rosemary leaves, distilled water (negative control) and CCLA (positive controls).

\begin{tabular}{|c|c|c|}
\hline Groups & $\begin{array}{r}\text { Dose } \\
\text { (mglkg) }\end{array}$ & $\begin{array}{c}\text { mean } \pm \text { standard error } \\
\text { (S.E.) } \\
\text { micronucleuslcells }\end{array}$ \\
\hline Positive controls(CCLA) & $\overline{0.2}$ & $2.280 \pm 0.012$ \\
\hline $\begin{array}{l}\text { Negative control (distilled } \\
\text { water) }\end{array}$ & 0.00 & $0.070 \pm 0.008^{B}$ \\
\hline Rosemary aqueous extract & 50 & $0.010 \pm 0.011^{A}$ \\
\hline Rosemary aqueous extract & 100 & $0.020 \pm 0.012{ }^{A}$ \\
\hline
\end{tabular}

Metaphase index of bone marrow cells after pre and post treatment

The Metaphase index of bone marrow cells was significantly increased as a consequence of pretreatment $(6.54 \pm 0.23,5.49 \pm 0.040$ vs. $3.65 \pm 0.40 \%)$, as well as in post treatment the metaphase index increased to $7.42 \pm 0.32,5.40 \pm 00.15 v s .4 .80 \pm 0.47 \%$ ) when mice treated with aqueous extract as compared to the corresponding controls Table (3).

Table (3): Metaphase index of bone marrow cells (mean \pm standard error) in albino male mice after interaction (pre and post treatment) between the two doses $(50 \mathrm{mglkg})$ and $(100 \mathrm{mglkg})$ of aqueous extract of rosemary leaves and CCLA.

\begin{tabular}{|c|c|c|}
\hline \multirow[t]{2}{*}{ Groups } & \multicolumn{2}{|c|}{$\begin{array}{c}\text { mean } \pm \text { stranded error } \\
(\%) \\
(\text { Metaphase index })\end{array}$} \\
\hline & $\begin{array}{c}\text { Pre- } \\
\text { Treatment }\end{array}$ & $\begin{array}{c}\text { Post- } \\
\text { Treatment }\end{array}$ \\
\hline control (distilled water-CCLA) & $3.65 \pm 0.40^{B}$ & $4.80 \pm 0.47^{C}$ \\
\hline $\begin{array}{c}\text { Rosemary aqueous extract } \\
\text { (50mgkg) }\end{array}$ & $6.54 \pm 0.23^{A}$ & $7.42 \pm 0.32^{\mathrm{A}}$ \\
\hline $\begin{array}{c}\text { Rosemary aqueous extract } \\
(100 \mathrm{mglkg})\end{array}$ & $5.49 \pm 0.040^{A}$ & $5.40 \pm 00.15^{\mathrm{B}}$ \\
\hline
\end{tabular}

Different letters in same column: significant difference $(\mathrm{P} \leq \mathbf{0 . 0 0 5})$ between means 


\section{Micronucleus Formation in Bone Marrow Cells After Pre- and Post- Treatment}

The distilled water (negative control) showed micronucleus index of $(0.160 \pm 0.001$ and $0.050 \pm 0.003$ micronucleus (cell), as a consequence of pre and post treatment with CCL4, respectively, the aqueous extract was able to modulate such effect in both types of treatment, and a reduction was observed as $(0.020 \pm 0.001$ and $0.070 \pm 0.002$ micronucleus $\backslash$ cells $)$ for $(50$ and $100 \mathrm{mg} \backslash \mathrm{kg})$ respectively in a pretreatment and $(0.020 \pm 0.010$ and $0.050 \pm 0.001$ micronucleus $\backslash$ cell, respectively) for $(50$ and $100 \mathrm{mg} \backslash$ $\mathrm{kg}$ ) in post treatment Table (4).

Table (4): Micronucleus formation in bone marrow cells (mean \pm standard error) in albino male mice after interaction (pre and post treatment) between the two doses $(50 \mathrm{mg} \mathrm{kg}$ ) of aqueous extract of rosemary leaves and CCLA.

\begin{tabular}{|c|c|c|}
\hline \multirow[t]{2}{*}{ Groups } & \multicolumn{2}{|c|}{$\begin{array}{c}\text { mean } \pm \text { stranded error } \\
(\%)\end{array}$} \\
\hline & $\begin{array}{c}\text { Pre- } \\
\text { Treatment }\end{array}$ & $\begin{array}{c}\text { Post- } \\
\text { Treatment }\end{array}$ \\
\hline $\begin{array}{c}\text { control (distilled water- } \\
\text { CCLA) }\end{array}$ & $0.160 \pm 0.0011^{A}$ & $0.050 \pm 0.003$ \\
\hline $\begin{array}{c}\text { Rosemary aqueous extract } \\
(50 \mathrm{mglkg})\end{array}$ & $0.020 \pm 0.001 c$ & $0.020 \pm 0.010^{B}$ \\
\hline $\begin{array}{c}\text { Rosemary aqueous extract } \\
(100 \mathrm{mgkg})\end{array}$ & $0.070 \pm 0.002^{B}$ & $0.050 \pm 0.001^{A}$ \\
\hline
\end{tabular}

Different letters in same column: significant difference $(\mathrm{P} \leq \mathbf{0 . 0 0 5})$ between means.

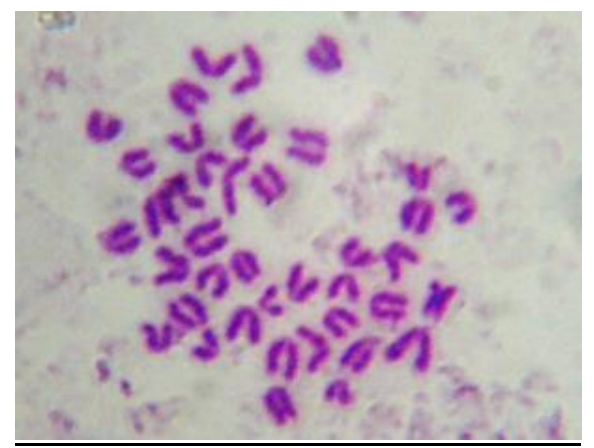

Fig (2): Bone marrow cell of normal mouse at metaphase (100X; Giemsa stain).

\section{Discussion}

Medicinal plants have long played crucial roles in the treatment of diseases all over the world [27]. In recent times, the beneficial effects of antioxidants, particularly natural antioxidants, used in the treatment and prevention of diseases, there has been a substantial interest in finding natural antioxidants from plant sources [28]. Rosemary officinalis possess a number of phytochemicals, including rosmarinic acid, camphor, caffeic acid, ursolic acid, betulinic acid, carnosic acid and carnosol which responsible for their roles [29] Several studies found that rosmarinic acid possessed anti-oxidant activity and was free radical scavengers [30]. Such effects can be achieved by diffrent metabolic pathways; for instances, inhibit the formation of free radicals, suppress chain initiation and/or breaking chain propagation reaction, increasing the activity of detoxifying enzymes such as glutathione transferase (GST) and superoxide dismutase (SOD) and de novo anti-oxidant and adaptation where the signal for the production and reaction of free radicals formation and transport of the anti-oxidant to the right site [31]. In addition to their immune modulatory effect, the flavonoid compounds serve other biofunctions, with special reference to antimutagenic activity. It has been demonstrated that the flavonoid compounds, 3-kameferolcoumate and luteolin, which were extracted from some plants of the family Lamiaceae (R. Officinalis, S. officinalis, Thymus vulgaris and Mentha piperita) inhibited the mutagenic activity of Trp-p-2, and the suggestion was that these compounds activate the metabolic inactivation by modifying the action of the enzyme cytochrome p450 enzyme [32]. Such consequence can lead to a 
decrease in DNA strand breaks, lipid peroxidation and cellular oxidation [33]. Another function of flavonoid compounds, in addition to antioxidant activity, it serves other bio-functions like antimutagenic and anti-tumor activities [34]. Antioxidant systems are frequently inadequate, and damage from reactive oxygen species is proposed to be involved in carcinogenesis [35]. Reactive oxygen species can damage DNA and division of cells with unrepaired or misrepaired damage can lead to mutations. If these changes appear in critical genes, such as oncogenes or tumor suppressor genes, initiation or progression may result. Reactive oxygen species can interfere directly with cell signaling and growth. The cellular damage caused by reactive oxygen species increases the risk of DNA damage and this will lead to mutations, and can increase the exposure of DNA to mutagens [36]. Flavonoids have also shown to inhibit nitric oxide in a dose dependently manner and also it has been reported that flavonoids have the most potent inhibitor of xanthine oxidase. Another possible mechanism by which flavonoids act on reactive oxygen species is through interaction with various enzyme systems, and some effects may be a result of a combination of radical scavenging and an interaction with enzyme functions [37]. The flavonoids content which possess anti-mutagenic and anti-tumor activities, play important role in the detoxification of mutagenic compounds [38]. These findings have also been further augmented to be involved in increasing the mitotic index of bone marrow which was observed in the present study. All these effects could be attributed to the chemical constituents of the plant with regard to the forthcoming repair mechanisms. It has been found that flavonoids en hances the postreplication repair and stimulates the mechanism of error-free repair [39].In addition to anti-oxidants and electrophile scavengers activity of flavonoids, another biological functions can be achieved; a stimulation of the immune system, inhibition of DNA adducts with carcinogens, inhibition of hormonal actions and metabolic pathway associated with the development of cancer, and inducing phase I or II detoxification enzymes [40].Significant reduced frequency of $\mathrm{MN}$ formation can be consequenced in the light of these functions and the results of this study suggest that the administration of R.officinalis is safe and with beneficial anti-mutagenic potential and has a protective effect on the DNA within the bone marrow cells of treated animals, as suggested by the reduced frequency of MN-induction [41].

\section{References}

1. Mamedov, N. (2012). Medicinal plants studies: history, challenges and prospective. J. Med Aromat Plants. 1:8.

2. Padulosi, S., Leaman, D. and Quek, P. (2002). Challenges and opportunities in enhancing the conservation and use of medicinal and aromatic plants. J Herbs Spices Med Plants . 9: 243-267.

3. Oluwatuyi, M., Kaatza, G.W. and Gibbons, S. (2004). Antibacterial and Resistance Modifying Activity of Rosmarinus officinalis. J. Phytochemistry. 65: 3249-3254.

4. Krause, A. J., Miracle, R. E., Sanders, T. H., Dean, L.L. and Drake, M.A. (2008). The Effect of Refrigerated and Frozen Storage on Butter Flavor and Texture. J. Dairy Science, 91:455-465.

5. Shiota, M., Takahashi, N., Konishi, H. and Yoshioka, T. (2012). Impact of Oxidized Off-Flavor of Ice Cream Prepared from Milk Fat. J. Oil and Fat Industries. 81: 455-460.

6. Lee, K.G. and Shibamoto, T. (2002). Determination of Antioxidant Potential of Volative Extracts Is olated from Various Herbs and Spices. J. Agricultural and Food Chemistry.50:4947-4952.

7. Ahmed, S. G. and Ahmed, F. S. (2015). Antioxidant Properties of Rosemary and Its Potential Uses as Natural Antioxidant in Dairy Products A Review. J. Food and Nutrition Sciences. 6: 179-193.

8. Hassani, F.V., Shirani, K. and Hosseinzadeh, H. (2016). Rosemary (Rosmarinus officinalis) as a potential therapeutic plant in metabolic syndrome: A review. Naunyn-Schmiedeberg's Arch. Pharmacol. 389: 931-949.

9. Almela, L., Sanchez-Munoz, B., Fernandez-Lopez, J. A., Roca, M. J. and Rabe, V. (2006). Liquid chromatographic-mass spectrometric analysis of phenolics and free radical scavenging activity of rosemary extract from different raw material. J. Chromatogr. A., 1120(1-2): 221-229.

10. Sasaki, K., El-Omri, A., Kondo, S., Han, J and Isoda, H. (2013). Rosmarinus officinalis polyphenols produceantin -depressant like effect through monoaminergic and cholinergic functions modulation. Behav. Brain Res. 238: 86-94.

11. Tai, J., Cheung, S., Wu, M. and Hasman, D. (2012). Antiproliferation effect of rosemary (Rosmarinusofficinalis) on human ovarian cancer cells in vitro. Phytomedicine. 19: 436-443.

12. Afonso, M.S., De, O., Silva, A.M., Carvalho, E.B., Rivelli, D.P., Barros, S.B., Rogero, M.M., Lottenberg, A.M., Torres, R.P. and Mancini-Filho, J. (2013). Phenolic compounds from Rosemary (Rosmarinus officinalis L.) attenuate oxidative stress and reduce blood cholesterol concentrations in diet-induced hypercholesterolemic rats. Nutr. Metab. 10: 19.

13. Rezzoug, S. A., Boutekedjiret, C. and Allaf, K. (2005). Optimization of operating conditions of rosemary essential oil extraction by a fast controlled pressure drop process using response surface methodology. Journal of Food Engineering, La Rochelle/Algiers . 71(1): 9-17. 
14. Fernandezlobez, J. (2005). Antioxidant and antibacterial activities of natural extracts: application in beef meatballs. Meat Science, Alicante/Newton Abbot. 69 (3): 371-380.

15. Leal, P. F. (2003). Functional Properties of Spice Extracts Obtained via Supercritical Fluid Extraction. Journal of Agricultural and Food Chemistry, Campinas. 51 (9): 2520-2525.

16. Saber, A. S., Sabah, F., El-Abd, Mohamed Osman, Asmaa, M., Kandi, 1. and Mona, S. Helmy. (2010). Effect of rosmary on carbon tetrachloride induecd hepatotoxicity in albino rats -histology and biochemical studies. Egyptian Society of Experimental Biology. 6 (1): 135 - 140

17. Saber, A. S. and Hawazen, A. (2012). Protective Effect of Rosemary (Rosmarinus Officinalis) Leaves Extract on Carbon Tetrachloride -Induced Nephrotoxicity in Albino Rats. Life Science Journal. 9: 1

18. Qiu, D., Hua, J., Li, J. and Li, E. (2005). CDI4 expression on Kupffer cells during the course of carbon tetrachloride-mediated liver injury. Chin. J. Dig. Dis. 6 (31):137-141.

19. Campo, M. G., Avenoso, A., Campo, S., Ascola, A., Ferlazzo, M.A, and Calatroni A. (2004). The antioxidant and antifibrogenic effects of the glycosaminoglycans hyaluronic acid and chondroitin -4sulphate in a subchronic rat model of CCl4-induced liver fibrgenesis. Chem-Biol. Interact. 148(3): 125138.

20. Jaramillo-Juárez, F., Rodríguez-Vázquez, M. L., Rincón-Sánchez, A. R., Consolación Martínez, M., Ortiz, G. G., Llamas, J., Anibal P.F. and Reyes, J. L. (2008). Acute renal failure induced by carbon tetrachloride in rats with hepatic cirrhosis. . Ann. Hepatol. 7(4):331-8.

21. Fua, W., Chena, J., Caia, Y., Leia, Y., Chenb, L., Peic, L., Zhoua, D., Lianga, X. and Ruana, J. (2010). Antioxidant, free radical scavenging, anti-inflammatory and hepatoprotective potential of the extract from Parathelypteris nipponica (Franch. et Sav.) Ching. J Ethnopharmacol., 130: 521-528.

22. Al-Ezzy, R.M. (2007). Immunological and Cytogenic Effect of Saga (Salivia officinalis) Leaves Extracts on Albino Male Mice and Acute Lymphoid Leukemic Cells. M.Sc. Thesis. Al-Nahrain University /college of science.

23. Arturo Anado’, N., Maria, R., Martínez-Larran , A.G.A., Maria, A., Martíne, Z., Irma, A., Monica, R., Garci', A-RISCO, Francisco, J., Senora, N.S. and Guillermo, R. (2008). Acute Oral Safety Study of Rosemary Extracts in Rats. J. of Food Protection, 71(4):790-795.

24. Allen, J.W., Shuler, C.V., Mendes, R.W. and Latt, S. A. (1977). A simplified technique for in vivo analysis of sister chromatid exchanges using 5-bromo-deoxy uridine tablets. Cytogenetics and Cell Genetics, 18: 231-37.

25. Schmid, W. (1976). The cell micronucleus test for cytogenes analysis in: Hollaender, A. (Ed.) Chemical Mutagens principles and Methods for their Detection. Volume Four. Plenum Press, New York and London. pp: 31-53.

26. Perez-Serrano, J., Denegri, G., Casado, N. and Fodriguez-Cabaeiro, F. (1997). In vivo effect of oral albendazole and albendazole sulphoxide on development of secondary echinococcosij in mice. Int $\mathrm{J}$ Parasitol., 27: 1341-1345.

27. Fallah-Hoseini, H., Fakhrzadeh, H., Larijani, B. and Shikhsamani. (2006). A. Review of anti-diabetic medicinal plant used in traditional medicine. J Med Plant. 5:1-8.

28. Mahmoud and Rafieian-Kopaei, M. (2012). Medicinal plants and the human needs. J. HerbMed Pharmacol. 1(1): 1-2.

29. Vallverdú-Queralt, A., Regueiro, J., Martínez-Huélamo, M., Rinaldi Alvarenga, J. F., Leal, L. N. and Lamuela-Raventos, R. M. (2014). "A comprehensive study on the phenolic profile of widely used culinary herbs and spices: Rosemary, thyme, oregano, cinnamon, cumin and bay". Food Chemistry. 154: 299-307.

30. Wang, M., Kikuzaki, H., Zhu, N., Sang, S., Nakatani, N. and Ho, C-T. (2000). Isolation and structure elucidation of two new glycosides from sage (Salvia officinalis). J. Agricultural and Food Cheistry, 48: 235-238.

31. Noguchi, N., Watanabe, A. and Shi, H. (2000). Free Radiation Research, 33: 809-817.

32. Samejima, K., Kanazawa, K., Ashida, H. and Danno, G. (1995). Luteolin:a strong antimutagin against dietary carcinogen 3-amino-1-methyl-5H-pyrido [4,3-10] indole (Trp-P-2). J. Agricultural and Food Chemistry, 46: 4864-86.

33. Kanazawa, K., Yamashita, T., Ashida, H. and Danno, G. (1998). Antimytagenicity of flavons and flavonols to heterocyclic amines by spesific and strong inhibition of the cytochrome P4501 A family. Bioscience Biotechnology Biochemistry. 62:970-77.

34. Hirata, F., Harada, T., Corcoran, G.B. and Hirata, A. (2014). Dietary flavonoids bind to monoubiquitinated annexin A1 in nuclei, and inhibit chemical induced mutagenesis . Mutat Res Fundam Mol Mech Mutagen. 759: 29-36.

35. Bauer, G. (2014). Targeting extracellular ROS signaling of tumor cells. Anticancer Res., 34: 14671482. 
36. Szczesny, B., Olah, G., Walker, D.K., Volpi, E., Rasmussen, B.B., Szabo, C. and Mitra, S. (2013). Deficiency in repair of the mitochondrial genome sensitizes proliferating myoblasts to oxidative damage. PLoS One. 8: 9.

37. Rathee, P., Chaudhary, H., Rathee, S., Rathee, D., Kumar, V. and Kohli, K. (2009). Mechanism of action of flavonoids as anti-inflammatory agents: a review. Inflamm Allergy Drug Targets. 8: 229-235.

38. Durgo, K., Vukovic, L, Rusak, G., Osmak, M. and Colic, J. F. (2009). Cytotoxic and Apoptotic Effect of Structurally Similar Flavonoids on Parental and Drug-Resistant Cells of a Human Cervical Carcinoma. Food Technol. Biotechnol, 47: 356-363.

39. Drummen, G. (2014). Flavonoid Thiol Toxicity: What's in a Group. Int J Mol Sci.

40. Takemura, H., Sakakibara, H., Yamazaki, S. and Shimoi, K. (2013). Breast cancer and flavonoids - a role in prevention. Curr Pharm Des., 19: 6125-6132.

41. Peron, A.P., Mariucci, R.G., de Almeida, I.V., Düsman, E., Mantovani, M.S. and Vicentini, V.E. (2013). Evaluation of the cytotoxicity, mutagenicity and antimutagenicity of a natural antidepressant, Hypericum perforatum L. (St. John's wort), on vegetal and animal test systems. BMC Complement Altern Med., 13: 97. 